\title{
JNPH
}

Volume 5 No. 1 (Juli 2017)

(C) The Author(s) 2017

\section{EFEKTIFITAS EKSTRAK KULIT BUAH JERUK PURUT (CITRUS HYSTRIX D.C) TERHADAP LARVA AEDES AEGYPTI L}

\author{
EFFECTIVENESS OF SKIN EXTRACT OF ORANGE FRUIT \\ (CITRUS HYSTRIX) ON LARVA AEDES AEGYPTI L
}

\author{
INAYAH HAYATI, I PUTU PEBRI KURNIAWAN \\ AKADEMI ANALIS KESEHATAN HARAPAN BANGSA BENGKULU \\ Email: naya1807@yahoo.co.id
}

\begin{abstract}
ABSTRAK
Ekstrak dari kulit buah jeruk purut (Citrus hystrix) sebagai biolarvasida Aedes aegypti dapat digunakan sebagai alternatif larvasida. Tujuan dari penelitian ini adalah untuk mengetahui efektifitas ekstrak kulit buah jeruk purut terhadap larva Aedes aegypty. Sampel dalam penelitian ini adalah larva Aedes aegypti instar III yang terdiri dari 6 kelompok perlakuan masing-masing berisi 25 ekor larva Aedes aegypti $L$ dan dilakukan 1 kali pengulangan. Konsentrasi pengenceran ekstrak yang digunakan $1 \%, 3 \%, 5 \%, 7 \%$, dan 9\%. Pengamatan dilakukan setelah $1 \times 24$ jam dan dihitung jumlah kematian larva. Analisa data dihitung presentase dari jumlah kematian larva kemudian dilakukan uji regresi. Hasil penelitian menunjukan bahwa ekstrak kulit buah jeruk purut (Citrus hystrix D.C) memiliki potensi sebagai biolarvasida terhadap larva Aedes aegypti L, konsentrasi 3\% - 9\% efektif untuk menghambat pertumbuhan larva yaitu didapatkan presentase sebesar 100\% kematian larva.
\end{abstract}

Kata kunci : ekstrak, citrus hystrix, Aedes agypti $L$.

\begin{abstract}
Extract from citrus fruits (Citrus hystrix) as Aedes aegypti biolarvasida can be used as an alternative to larvacide. The purpose of this study was to determine the effectiveness of orange peel extracts against Aedes aegypty larvae. The sample in this study was Aedes aegypti intar III larvae consisting of 6 treatment groups each containing 25 Aedes aegypti larvae and 1 repetition. The concentration of dilution extract used was $1 \%, 3 \%, 5 \%, 7 \%$, and $9 \%$. Observations were performed after 1x24 hours and counted the number of larva deaths. Data analysis calculated percentage of larva mortality then regression test. The results showed that the extract of citrus hystrix has potency as biolarvaside to Aedes aegypti larvae L, concentration of $3 \%-9 \%$ effective to inhibit larval growth that is obtained percentage of $100 \%$ death of larvae.
\end{abstract}

Keywords: extract, citrus hystrix, aedes agypti $L$.

PENDAHULUAN

Penyakit Demam Berdarah Dengue (DBD) merupakan penyakit menular dengan vektor nyamuk Aedes aegypti. Kementerian
Kesehatan RI mencatat jumlah penderita DBD di Indonesia pada bulan JanuariFebruari 2016 sebanyak 8.487 orang penderita DBD dengan jumlah kematian 108 orang. Golongan terbanyak yang mengalami 
DBD di Indonesia pada usia 5-14 tahun mencapai 43,44\% dan usia 15-44 tahun mencapai 33,25\%. Kota Bengkulu merupakan slah satu dari 11 provinsi di Indonesia yang pada bulan Januari-Februari 2016 Kejadian Luar Biasa (KLB) penyakit DBD (Kemenkes RI, 2016).

Dinas Kesehatan Provinsi Bengkulu mencatat ada 511 kasus demam berdarah dengue (DBD) sejak Januari hingga 17 Februari 2016 dengan jumlah kasus terbanyak di Kota Bengkulu dan Kabupaten Kepahiang. Pada Januari 2016 Dinkes mencatat ada 297 kasus DBD dan sebanyak 214 kasus sejak 117 Februari 2016. Dari jumlah kasus tersebut, pasien terjangkit DBD yang meninggal dunia sebanyak 11 orang (Antara, 2016).

Vektor penyakit DBD adalah nyamuk Aedes aegypti $L$ yang penyebarannya harus dihambat. Upaya pengendalian vektor dapat dilakukan dengan metode fisik, biologi maupun kimiawi. Salah satu cara pengendalian vektor demam berdarah adalah dengan menggunakan insektisida sintetik seperti DDT (Dichloro Diphenyil Trichloroethane), etiheksanol, tamefos, dan berbagai senyawa sintetik lainnya (Gandahusda, 2003). Penggunaan insektisida sintetis khususnya larvasida menimbulkan beberapa efek diantaranya adalah resistensi terhadap serangga, pencemaran lingkungan, dan residu insektisida. Untuk mengurangi efek tersebut, maka diupayakan penggunaan larvasida alami untuk mengendalikan larva Aedes sp. Larvasida alami relatif mudah dibuat dengan kemampuan dan pengetahuan yang terbatas. Oleh karena terbuat dari bahan alami, maka jenis insektisida ini mudah terurai karena residunya mudah hilang. Larvasida alami bersifat hit and run, yaitu apabila diaplikasikan akan membunuh hama pada waktu itu dan setelah hamanya terbunuh akan cepat menghilang di alam (Kardinan, 2000)

Pemilihan bahan yang akan digunakan sebagai larvasida tentunya harus aman terhadap manusia atau pun organisme lain, selain itu bahan juga mudah didapatkan dan diharapkan dapat memberi dampak positif pada kesehatan manusia. Oleh karena itu, salah satu alternatif cara pengendalian nyamuk demam berdarah adalah dengan memanfaatkan tanaman yang banyak tumbuh di Indonesia dan sudah sering digunakan masyarakat. Salah satu upaya untuk mengatasi masalah tersebut adalah dengan mencari sarana pengendalian alternatif yang dapat mengendalikan vektor penyakit DBD (Aedes aegypti L) dengan pencegahan pertumbuhan larva nyamuk instar III secara efektif tetapi ramah lingkungan yaitu pemanfaatan kulit jeruk purut (Citrus hystrix D.C). Kandungan senyawa kimia pada jeruk purut yang dapat digunakan sebagai biolarvasida meliputi senyawa minyak atsiri, flavonoid, saponin dan terpen pada daun jeruk purut yang bekerja sebagai racun pada larva nyamuk baik sebagai racun kontak maupun racun perut. ((Adrianto, et al., 2014).

Tujuan dari penelitian ini adalah untuk mengetahui efektifitas ekstak kulit buah jeruk purut (Citrus hystrix) terhadap larva Aedes aegypty dan konsentrasi yang paling efektif dari ekstrak kulit jeruk purut sebagai larvasida.

\section{METODE PENELITIAN}

Penelitian ini dilaksanakan di Laboratorium FMIPA Biologi Unib untuk proses ekstraksi dan Laboratorium Parasitologi Akademi Analis Kesehatan Harapan Bangsa Bengkulu untuk uji biolarvasida pada larva nyamuk Aedes aygypti $L$ instar III \& IV pada tanggal 04 April - 25 Juni 2016. Populasi dalam penelitian ini adalah buah jeruk purut (Citrus hystrix) sebanyak $8 \mathrm{~kg}$. Sampel dalam penelitian ini adalah ekstrak kulit buah jeruk purut (Citrus hystrix DC) kering sebanyak 750 gram dengan konsentrasi pengenceran $1 \%, 3 \%, 5 \%, 7 \%, 9 \%$ dan kontrol negatif menggunakan Aquadest. Jenis Penelitian eksperimen laboratorium dengan melihat efek larvasida kulit buah jeruk purut terhadap larva Aedes aegypti $L$ setelah perlakuan selama 24 jam.

Alat yang digunakan dalam penelitian ini 
adalah 1 set alat Rotary Evaporator, Gelas ukur $10 \mathrm{ml}$, Wadah penyimpanan, Blender, Erlenmeyer $250 \mathrm{ml}$, Kertas saring, Gelas ukur $10 \mathrm{ml}$, pipet tetes, lidi, batang pengaduk, Beaker glass sedangkan bahan yang digunakan adalah kulit buah jeruk purut masak kering (Cytrus histrix DC) sebanyak 750 gr dan Cairan penyaring Etanol $\left(\mathrm{C}_{2} \mathrm{H}_{6} \mathrm{O}\right)$ 96\% sebanyak 6 Liter.

\section{CARA KERJA}

\section{Pembuatan Ekstrak Kulit Jeruk Purut (Cytrus histrix D.C)}

Ekstrak kulit jeruk purut yang didapat dari kulit buah jeruk purut masak sebanyak 8 kg di cuci bersih, kupas jeruk lalu dipisahkan antara buah dan kulit jeruk. kulit jeruk dipotong kecil dikeringkan kemudian dihaluskan menggunakan blender dan maserasi dengan menggunakan cairan penyaring etanol 96\%. Didapat serbuk kulit buah jeruk purut (Cytrus histrix) sebanyak 750 gram dimaserasi dengan 2 Liter etanol 96\% selama 3 hari remaserasi dilakukan sebanyak 3 kali. Filtrat dipekatkan menggunakan rotary evaporator pada suhu $50^{0} \mathrm{C}$ dengan kecepatan $3000 \mathrm{rpm}$ dan dilanjutkan menggunakan oven pada suhu $50^{0} \mathrm{C}$ selama $1 \times 24$ jam hingga ekstrak kental .

\section{Uji Efek Larvasida Ekstrak Kulit Jeruk Purut (Cytrus histrix DC)}

Ekstrak Kulit Jeruk Purut diambil dan diukur sesuai dengan konsentrasi yang akan dipakai lalu dimasukkan pada masing-masing labu ukur. Konsentrasi ekstrak kulit jeruk yang di gunakan $1 \%, 3 \%, 5 \%, 7 \%, 9 \%$ dan kontrol (-) menggunakan aquadest. Ekstrak yang sudah diukur sesuai dengan konsentrasi dimasukan kedalam labu erlenmeyer $250 \mathrm{ml}$ dan tambahkan aquadest hingga volume 100 ml, masukkan 25 ekor larva Aedes aegypti L instar III dan IV pada setiap erlenmeyer tanpa di beri makan termasuk kontrol. Pemilihan Larva Instar III dan IV berdasarkan ciri-ciri serta pengamatan pada mikroskop. Jumlah larva yang mati dihitung setelah 24 jam sejak diberi perlakuan.

\section{Teknik Pengumpulan dan analisa data}

Penelitian ini menggunakan data primer dengan melakukan pemeriksaan secara langsung efek biolarvasida ekstrak kulit buah jeruk terhadap larva Aedes aegypti $L$ pada konsentrasi 1\%, 3\%, 5\%, 7\%, 9\% dan kontrol (-) menggunakan Aquadest data dianalisis secara deskriptif dan dengan uji regresi setelah diperoleh hasil kematian larva pada masing-masing konsentrasi perlakuan.

\section{HASIL PENELITIAN}

Berdasarkan penelitian yang dilakukan didapatkan hasil kematian larva Aedes aegypti $L$ seperti yang terlihat pada tabel 1 berikut:

\section{Tabel 1. Hasil uji ekstrak kulit jeruk purut (Citrus hystrix D.C) terhadap larva Aedes aegypti $L$ selama $1 \times 24$ jam}

\begin{tabular}{|c|c|c|c|c|c|c|}
\hline \multirow{3}{*}{$\begin{array}{l}\text { Perlakuan } \\
\begin{array}{c}\text { Perlakuan } \\
\text { I }\end{array}\end{array}$} & \multicolumn{6}{|c|}{ Konsentrasi perlakuan Ekstrak Kulit Jeruk } \\
\hline & \multicolumn{6}{|c|}{ Kontrol(-) $1 \% \quad 5 \% \quad 7 \% \quad 9 \%$} \\
\hline & 0 & 21 & 25 & 25 & 25 & 25 \\
\hline $\begin{array}{l}\text { Perlakuan } \\
\text { II }\end{array}$ & 0 & 23 & 25 & 25 & 25 & 25 \\
\hline $\begin{array}{c}\text { Jumlah } \\
\text { Kematian } \\
\text { Larva } \\
\text { (ekor) }\end{array}$ & 0 & 44 & 50 & 50 & 50 & 50 \\
\hline $\begin{array}{c}\text { Rata-rata } \\
\text { Kematian } \\
\text { Larva }\end{array}$ & 0 & 22 & 25 & 25 & 25 & 25 \\
\hline $\begin{array}{c}\text { Presentase } \\
\%\end{array}$ & $0 \%$ & $88 \%$ & $100 \%$ & $100 \%$ & $100 \%$ & $100 \%$ \\
\hline
\end{tabular}

Ket : Jumlah larva uji sebanyak 25 ekor larva Aedes aegypti $L$ pada masing -masing konsentrasi.

Berdasarkan hasil pada tabel 1, kemudian dilakukan uji regresi terhadap Aedes aegypti $L$ dengan biolarvasida ekstrak kulit jeruk purut maka didapatkan hasil regresi dengan $\mathrm{R}^{2}=0,20$ dengan persamaan y 
$=3,763 \mathrm{x}$ seperti yang terlihat pada grafik berikut:

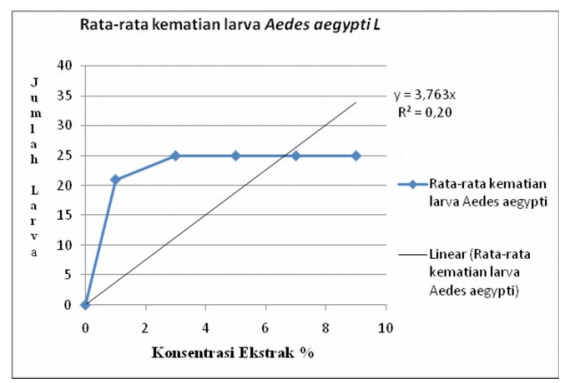

Grafik 1. Hasil uji regresi terhadap jumlah kematian larva Aedes aegypti $L$.

\section{PEMBAHASAN}

Setelah dilakukan penelitian Pada konsentrasi kontrol (-) menggunakan aquadest tidak terjadi kematian larva Aedes aegypti $L$ selama 24 jam sehingga rata -rata kematian larva uji adalah 0. Sedangkan dari berbagai konsentrasi ekstrak jeruk purut yang digunakan ekstrak kulit buah jeruk purut memiliki efek membunuh larva nyamuk Aedes aegypti L.

Pada konsentrasi ekstrak kulit jeruk purut 1\% didapatkan jumlah kematian larva Aedes aegypti $L$ sebanyak 21 ekor pada perlakuan pertama dan sebanyak 23 ekor pada perlakuan kedua dengan rata-rata 22 dan presentase kematian sebesar $88 \%$. Hal ini berarti ekstrak kulit jeruk dengan konsentrasi $1 \%$ belum sepenuhnya mampu membunuh atau menghambat pertumbuhan larva Aedes aegypti $L$, hal ini mungkin dikarenakan konsentrasinya yang terlalu rendah.

Selanjutnya pada konsentrasi ekstrak kulit jeruk purut 3\% didapatkan jumlah kematian larva Aedes aegypti $L$ sebanyak 25 ekor pada perlakuan pertama dan sebanyak 25 ekor pada perlakuan pertama dan sebanyak 25 ekor pada perlakuan kedua dengan rata-rata 25 dan presentase kematian sebesar $100 \%$. Pada konsentrasi ini juga sangat efektif didapatkan hasil jumlah kematian semua larva Aedes aegypti L. Kemudian pada konsentrasi ekstrak jeruk purut 5\% didapatkan jumlah kematian larva Aedes aegypti L sebanyak 25 dan presentase kematian sebesar 100\%. Pada konsentrasi ini juga sangat efektif didapatkan hasil jumlah kematian semua larva Aedes aegypti $L$.

Pada konsentrasi ekstrak kulit jeruk 7\% didapatkan jumlah kematian larva Aedes aegypti $L$ sebanyak 25 ekor pada perlakuan pertama dan sebanyak 25 ekor pada perlakuan kedua dengan rata-rata 25 dan prensentase kematian sebesar $100 \%$. Pada konsentrasi ini juga sangat efektif didapatkan hasil jumlah kematian semua larva Aedes aegypti L. Pada konsentrasi ekstrak kulit jeruk purut 9\% didapatkan jumlah kematian larva Aedes aegypti $L$ sebanyak 25 ekor pada perlakuan pertama dan sebanyak 25 ekor pada perlakuan kedua dengan rata-rata 25 dan presentase kematian sebesar $100 \%$.

Pada tabel 1 terlihat bahwa semakin tinggi konsentrasi ekstrak kulit jeruk purut maka jumlah kematian larva uji semakin banyak. .Setelah diketahui jumlah kematian larva Aedes aegypti L kemudian dilakukan uji regresi untuk melihat kemampuan konsentrasi ekstrak kulit jeruk purut dengan hasil kematian larva Aedes aegypti $L$ pada keenam kelompok perlakuan. Garis linier yang dihasilkan menyatakan bahwa semakin tinggi konsentrasi yang dipakai maka jumlah kematian larva juga semakin tinggi. Sehinga ekstrak kulit jeruk purut memiliki potensi biolarvasida terhadap larva Aedes aegypti $L$ instar III dan IV. Sehingga dapat disimpulkan bahwa pemberian ekstrak kulit buah jeruk purut sangat efektif digunakan dalam pengendalian vektor yaitu mematikan larva nyamuk Aedes aegypti $L$. sebagaimana menurut Devy et al (2010) Tanaman jeruk purut digunakan sebagai biolarvasida karena mengandung senyawa Limonida. Racun ekstrak kulit buah jeruk purut merupakan racun kontak yang selanjut terlebih dahulu mengenai ekstrak kulit buah jeruk purut melalui kutikula yang mengakibatkan tubuh larva bergerak cepat yang kemudian racun terminum dan masuk kedalam tubuh serangga melalui mulut (Triharsi, 1994 dalam Faiqotul, 2011). 


\section{KESIMPULAN}

Berdasarkan hasil penelitian dan pembahasan maka dapat disimpulkan bahwa kulit buah jeruk purut (Citrus hystrix) memiliki potensi sebagai biolarvasida terhadap larva Aedes aegypti $L$ dan semakin tinggi konsentrasi ekstrak kulit buah jeruk purut yang dipakai maka daya bunuh terhadap larva Aedes aegypti semakin besar.

\section{SARAN}

Untuk lebih mengetahui potensi kulit buah jeruk purut (Citrus hystrix D.C.) yang dapat menyebabkan kematian larva nyamuk Aedes aegypti L., maka diperlukan penelitian lebih lanjut mengenai senyawa aktif yang lebih murni sehingga dapat diketahui jenis senyawa yang bersifat sebagai biolarvasida tersebut.

\section{DAFTAR PUSTAKA}

Adrianto, H., Yotopranooto, S., Hamidah. (2014). Efektifitas Ekstrak Daun Jeruk Purut (Cytrus hystrix), Jeruk Limau (Citrus amblycarpa), dan Jeruk Bali (Citrus maxima) Terhadap Larva Aedes aegypti. Aspirator.Vol 6 (1) : 1-6

Antara. Editor Musriadi. (2016). Bengkulu catat 511 kasus DBD selama 2016. http://www.antarabengkulu.com/berita/3 5811/bengkulu-catat-511-kasus-dbdselama-2016. Kamis, 18 Februari 2016 14:49 WI

Faiqotul, 2011, Uji Efektivitas Antara Ekstrak Daun Tumbuhan Tapak Dara (Catharanthus roseus) dan Daun Jeruk Nipis (Citrus aurantifolia) Sebagai Biolarvasida Instrar III Nyamuk Aedes aegypti, Fakultas Sains dan Teknologi, Universitas Airlangga, Surabaya.

Gandahusada,S. 2003. Parasitologi Kedokteran. Edisi II, Jakarta : FKUI

Kardinan, Agus. (2000). Pestisida Nabati, Ramuan dan Aplikasinya. Penebar Swadaya. Jakarta.

Kementerian Kesehatan RI. (2016). Wilayah
KLB DBD ada di 11 Provinsi. http://www.depkes.go.id/article/print/160 30700001/wilayah-klb-dbd-ada-di-11provinsi.html. artikel. 